Chantal Reynier, Comment l'Évangile a changé le monde (Études bibliques;

Paris: Les Éditions du Cerf 2018) Ss. 338. € 24. ISBN 9782204122627.

\title{
PAWEK PODESZWA
}

\author{
Wydział Teologiczny, Uniwersytet im. Adama Mickiewicza w Poznaniu \\ e-mail: podpaw@amu.edu.pl \\ ORCID: 0000-0002-4000-1660
}

Papież Benedykt XVI w adhortacji apostolskiej Verbum Domini nazwał Biblię „wielkim kodem kulturowym” (nr 110) i przypomniał, że „Słowo Boże na przestrzeni wieków inspirowało różne kultury, czego owocem były podstawowe wartości moralne, znakomite formy sztuki i wzorcowe style życia" (nr 109), a związek ,między słowem Bożym i kulturą znalazł wyraz w dziełach z różnych dziedzin, zwłaszcza w świecie sztuki” (nr 112). Nawiązując także do nauczania Jana Pawła II zaznaczył, że „w Piśmie świętym zawierają się wartości antropologiczne i filozoficzne, które miały pozytywny wpływ na całą ludzkość" (nr 110).

Recenzowana publikacja francuskiej biblistki Chantal Reynier z Centre Sèvres w Paryżu jest udaną próbą ukazania, w jaki sposób Ewangelia, to znaczy Dobra Nowina przyniesiona przez Jezusa z Nazaretu - Syna Bożego i Mesjasza Izraela - zmieniała świat, w którym była głoszona przez pierwsze pokolenia uczniów Jezusa, a zwłaszcza Pawła Apostoła. Choć temat nie jest nowy i można znaleźć szereg publikacji na temat wpływu Biblii, a szczególnie listów Pawłowych, na kulturę ówczesnego świata, to jednak warto zapoznać się z tym opracowaniem, gdyż w sposób bardzo przekonywający ukazuje ono główne tematy myślenia i nauczania Pawła Apostoła, które miały pozytywny, niejednokrotnie wręcz rewolucyjny, wpływ na ówczesny świat. Autorka we wstępie zaznacza, że nie ma zamiaru przedstawić wyczerpującego studium myśli Pawłowej ani też pełnego traktatu na temat oryginalności chrześcijaństwa. Określa swoją publikację jako esej, w którym chce zaprezentować osobliwości wiary chrześcijańskiej oraz nadziei, której wiara jest gwarantem. W tym celu dokonuje selekcji materiału Pawłowego, wydobywając i omawiając treści szczególnie ważne dla pierwszych wyznawców Chrystusa i jednocześnie aktualne dla współczesnych chrześcijan (s. 9). Warto także od razu zauważyć, że szukając oryginalności chrześcijańskich prawd wyrażanych przez Pawła, często konfrontuje myśl apostoła z poglądami innych autorów starożytnych. To porównanie jest konieczne, gdyż nie tylko ubogaca naszą wiedzę o tamtym kontekście społecznym, religijnym, kulturowym, 
w którym głoszona jest Ewangelia Jezusa, ale pozwala dostrzec wyjątkowość chrześcijańskiego nauczania i jego oryginalność w porównaniu z ówczesnymi przekonaniami, nie tylko religijnymi.

Struktura książki jest bardzo przejrzysta i logiczna. Ch. Reynier podzieliła ją na cztery zasadnicze części, na które składa się dwanaście rozdziałów. Rozpocznę od zaprezentowania głównych tematów omówionych w opracowaniu.

Pierwsza część, obejmująca trzy rozdziały, w sposób trafny i bardzo syntetyczny ukazuje absolutną nowość wiary chrześcijańskiej na tle ówczesnych pogańskich koncepcji religijnych. Podstawowe pytanie, na które próbuje odpowiedzieć autorka, brzmi: czy chrześcijaństwo było tylko jeszcze jedną religią ówczesnego świata, czy raczej głosiło prawdy diametralnie różne od ówcześnie panujących przekonań religijnych? Innymi słowy, są to pytania: o jakim Bogu mówią chrześcijanie? Kim On jest? jak Go rozumieją? jaki On jest?

Autorka najpierw koncentruje uwagę czytelnika na Bogu, który pozostając transcendentny, jest jednocześnie niezwykle bliski człowiekowi, co już czyni go całkowicie różnym od bogów greckiego i rzymskiego panteonu. Bóg Ojciec objawił swoją nieskończoną miłość każdej istoty ludzkiej zwłaszcza w misterium paschalnym swojego Syna. Stąd jak słusznie przypomina autorka, to właśnie zmartwychwstanie jest fundamentem wiary chrześcijańskiej, a jej „sercem” pozostaje zawsze Jezus Chrystus ukrzyżowany i zmartwychwstały. To w Nim chrześcijanie rozpoznają oczekiwanego Mesjasza Izraela. Jednak przyjście Mesjasza i Jego dzieło dokonują się w sposób radykalnie różny od wyobrażeń czy oczekiwań ludzkich. To sprawiło, że Jezus stał się „,zgorszenie dla Żydów, głupstwem dla pogan, dla tych zaś, którzy są powołani, tak spośród Żydów, jak i spośród Greków, Chrystusem, mocą Bożą i mądrością Bożą" (1 Kor 1,23-24). I jak jasno zaznacza Paweł, właśnie dlatego nie chce znać „niczego więcej, jak tylko Jezusa Chrystusa, i to ukrzyżowanego" (1 Kor 2,2). Przywołując właśnie tę myśl, autorka wyjaśnia także zbawczy sens śmierci Jezusa na krzyżu. To właśnie w skandalu krzyża objawia się prawda, że Bóg, Ojciec Jezusa i nasz Ojciec, nie tylko nie opuszcza Syna w momencie śmierci, ale ukazuje się jako Ten, który daje życie. I ten dar życia jest dla wszystkich. Bóg nie jest już Bogiem ukrytym, jak wiele bóstw w ówczesnych kultach pogańskich.

Zdaniem francuskiej biblistki bardzo ważny i warty podkreślenia jest fakt, że pierwsi chrześcijanie byli jednoznacznie kojarzeni z osobą Chrystusa, o czym świadczy także nazwa „,chrześcijanie”, której zaczęto używać na ich określenie w Antiochii i Rzymie. Byli oni zatem postrzegani jako wyznawcy, to znaczy naśladowcy Chrystusa, tak bardzo związani ze Zmartwychwstałym i Jego losem, co też było nowością w ówczesnej epoce i kulturze, w której żyli. I nawet jeśli samo wydarzenie zmartwychwstania bulwersowało czy gorszyło świat, to zostało ono potwierdzone przez naocznych świadków, którzy w Galilei, Judei i Jerozolimie widzieli i dotykali Zmartwychwstałego (zob. 1 J 1,1-4). A skoro 
w tym nieoczekiwanym wydarzeniu paschalnym została pokonana śmierć, która ma charakter powszechny, gdyż dotyczy każdego człowieka, to radosna i dobra nowina o nowym życiu, jest także dla każdego i należy ją głosić aż po wszystkie krańce ziemi (zob. Dz 1,8). Przekonanie o uniwersalności zbawienia w Jezusie z jednej strony sprawiło, że chrześcijanie niemal od samego początku podjęli dzieło ewangelizacji ówczesnego świata, z drugiej zaś spowodowało, że chrześcijaństwo nie stało się hermeneutyczną sektą, ale było otwarte dla wszystkich. Do grona owych wiarygodnych świadków zaliczał się także Paweł, gdyż spotkał Jezusa zmartwychwstałego pod Damaszkiem (1 Kor 15,8). Jest on przykładem chrześcijanina, którego ,życie staje się kerygmatyczne, a jego misja uniwersalna" (s. 33). Chodziło w niej przede wszystkim o umożliwienie innym ludziom poznania Boga, który nie ma nic wspólnego z pogańskimi bóstwami ówczesnego świata.

Drugi rozdział pierwszej części poświęcony został misji głoszenia Jezusa ukrzyżowanego i zmartwychwstałego. Czytelnik ma najpierw okazję zapoznać się z Pawłowym rozumieniem Ewangelii, którą apostoł otrzymał od Chrystusa, ale także z tradycji wspólnoty, czego był świadomy (zob. 1 Kor 15,1-5). Dla Pawła przepowiadanie Ewangelii to głoszenie Jezusa ukrzyżowanego i zmartwychwstałego. Nie brak w nim oczywistych odniesień do Jego życia, nauczania i znaków. Jednak Paweł odwołuje się do nich w nieco inny sposób niż ewangeliści: nie cytuje Jezusa, nie opowiada o wszystkich zdziałanych przez Niego cudach, choć - jak wykazuje autorka - apostoł zna doskonale życie i nauczanie Jezusa, czego wymownym świadectwem są liczne aluzje, które czyni w swoich listach. W centrum nauczania Pawła pozostaje jednak kerygmat chrześcijański o śmierci i zmartwychwstaniu Jezusa oraz o znaczeniu misterium paschalnego dla życia człowieka. Stąd apostoł bardzo często przypomina o włączeniu chrześcijan poprzez wiarę i chrzest w tajemnicą paschalną Jezusa (zob. Rz 6,1-11). Trzeba zgodzić się zatem z Reynier, która w podsumowaniu drugiego rozdziału (s. 52-53) stwierdza, że podczas gdy ewangeliści interesują się wędrówką Jezusa między ludźmi, kładąc oczywisty akcent na Jego słowa, spotkania, dokonane cuda, oraz opowiadają o męce, zmartwychwstaniu i epifaniach paschalnych, to Paweł - zafascynowany Chrystusem zmartwychwstałym - stara się odkrywać stopniowo to, co Jego wcielenie oraz misterium paschalne oznaczają dla świata. Paweł korzysta z nauczania Jezusa, które zna $\mathrm{z}$ tradycji ustnej, jako fundamentu, na którym buduje swoje przepowiadanie (zob. 1 Kor 3,10). Jego centrum stanowi zmartwychwstanie Jezusa, będące siła witalną dla całej ludzkości. Apostoł stara się zatem mówić i pisać o implikacjach tego faktu dla życia codziennego, a także o nadziei, którą daje zmartwychwstanie światu, rozpaczliwie szukającego sensu życia.

Ostatni rozdział pierwszej części dotyczy portretu Jezusa, jaki daje Paweł w swoich listach. Bazuje on na objawieniu, które otrzymał, ale także na oso- 
bistym doświadczeniu. Dzisiaj niektórzy, nie negując historyczności Jezusa, uznają Go jednak za mędrca na wzór Sokratesa albo zwolennika braku przemocy takiego jak Gandhi. Także dla Pawła Jezus jest Mistrzem mądrości, ale tej pochodzącej od Boga, która jest całkowicie inna od ludzkiej (zob. 1 Kor 2,7). Jest to bowiem mądrość krzyża, którą można poznać tylko w miłości i poprzez miłość. Kim jest Jezus według Pawła? Mistrzem jakiej mądrości Bożej pozostaje? Na te pytania Reynier odpowiada, przywołując określenia Jezusa, które pojawiają się w listach Pawła Apostoła: Syn Boży w ciele, Zbawiciel, Syn Boży w chwale, jedyny Sprawiedliwy, Pośrednik, Chrystus Stworzyciel i Pierworodny wszelkiego stworzenia, Syn Boży wzór człowieka i Głowa Kościoła, Jezus jako rekapitulacje wszystkich rzeczy. Omawiając te charakterystyczne Pawłowe tytuły chrystologiczne, autorka podkreśla, że w Jezusie mamy jednocześnie kontynuację i nowość. Z jednej strony jest Tym, który zrywa z Prawem i ogłasza je jako „przeklęte”, z drugiej jest całkowitym jego wypełnieniem, a tym samym realizacją obietnic danych Izraelowi. W ten sposób Jezus kładzie kres jedynemu porządkowi Prawa i wskazuje na radykalną nowość, która przychodzi wraz z Nim: Prawo przestaje być jedyną drogą dostępu do Boga. Jest nią teraz wyłącznie Ukrzyżowany - „droga, prawda i życie” (J 14,6), jednocześnie jednak przypominając, że Pismo Święte pozostaje ciągle nieodzowne w zbliżeniu się do Boga objawienia.

Druga część książki poświęcona została oryginalności i nowości antropologii chrześcijańskiej, która ma podstawy przede wszystkim w tym, że Syn Boży przyjął we wcieleniu ludzką naturę i objawił człowiekowi, w jaki sposób powinien przeżywać swoje człowieczeństwo. W pierwszym rozdziale tej części biblistka przedstawia nową wizję człowieka, w której Chrystus, będący „człowiekiem doskonałym, drugim i ostatnim Adamem" (1 Kor 15,45), jest kluczem do zrozumienia, kim naprawdę jest każdy człowiek. W Chrystusie poznajemy bowiem nowego człowieka. Jest on jednocześnie „człowiekiem wewnętrznym” (2 Kor 4,16).

Nowością antropologii Pawła jest przekonanie, że wszyscy ludzie są braćmi, ponieważ każdy otrzymuje życie od ,,jednego Boga, Ojca wszystkich” (Ef 4,6). Nowość wiary chrześcijańskiej niweluje zatem wszelkie podziały etniczne, religijne, społeczne (zob. Ga 3,27-28). Chrystus staje się zatem zasadą jedności ludzi, którzy zakorzenieni w Nim i włączeni w Jego śmierć i zmartwychwstanie stają się jedno z Nim (zob. Rz 6,5). Jak słusznie zauważa autorka, taka właśnie wizja człowieka jest dzisiaj niezwykle aktualna i trzeba, aby była poważnie traktowana przez wyznawców Jezusa. Domaga się ona jednak ciągłego wychowywania osoby ludzkiej „w świetle Zmartwychwstałego” (s. 87). Istotna nowość antropologii chrześcijańskiej tkwi także w tym, że wiara przynosi odpowiedź na pytanie o przyszłość ludzkości. 
Śmierć została pokonana raz na zawsze i stąd obietnica zmartwychwstania dla wszystkich, bazująca w oczywisty sposób na fakcie zmartwychwstania Jezusa.

Misterium paschalne rzuca nowe światło także na doświadczenia człowieka, zwłaszcza te trudne i wymagające, jak cierpienie, prześladowanie, a ostatecznie śmierć. Paweł ma odwagę powiedzieć, że mimo tych negatywnych i bolesnych doświadczeń, z którymi boryka się człowiek, ,jesteśmy wielkimi zwycięzcami” (Rz 8,37), gdyż nie są one w stanie w żaden sposób zmienić czy osłabić definitywnego zwycięstwa Chrystusa nad śmiercią. To On ostatecznie jest dla świata źródłem nadziei, że zło nigdy nie zwycięży, bo już zostało pokonane.

W kolejnym rozdziale drugiej części Reynier wyjaśnia, w jaki sposób chrześcijańska antropologia ,uczłowieczyła” byt ludzki. Najpierw dokonało się to poprzez wezwanie człowieka do życia jako syn Boży poprzez uświęcenie i naśladowanie samego Boga. Ten sposób życia zostaje porównany do „chodzenia według Ducha”, który prowadzi ludzi i ich wychowuje na wzór samego Jezusa (zob. 1 Tes 4,1-2). Dlatego właśnie życie chrześcijan, będące odpowiedzią na otrzymane zadanie naśladowania Boga i Jezusa, musi odróżniać się od pogańskiego sposobu myślenia i życia (zob. Ef 4,17). Trzeba iść drogami miłości (zob. Ef 5,2) i mieć te same dążenia, które są w Chrystusie (zob. Flp 2,5). To jest nie tylko wielkie wewnętrzne wezwanie każdego chrześcijanina, ale także świadectwo tego nowego sposobu życia wyznawców Jezusa, dzięki któremu może On nadal przemieniać człowieka i świat, w którym żyjemy. Także ta prawda wydaje się być dzisiaj bardzo aktualna.

W ostatnim rozdziale drugiej części autorka publikacji, na podstawie nauczania Pawła, przypomina, co jest niezbędne, aby uczeń Jezusa mógł żyć zgodnie ze swoim powołaniem nowego człowieka, który naśladuje swojego Mistrza. Na pierwszy plan wysuwa się niewątpliwie konieczność nieustannego poszukiwania woli Boga, co ostatecznie dokonuje się dzięki Duchowi Świętemu. Rozpoznając to, co jest sprawiedliwe, czyli zgodne z Bożymi oczekiwaniami, naśladując Jezusa, chrześcijanin staje się światłością świata (zob. Ef 5,2). Reynier zwraca także uwagę, że w tym procesie wzrastania w wierze niezwykle ważne jest formowanie sumienia. Oznacza to także gotowość walki w samym sobie, gdyż pragnąc żyć według Ducha Bożego, a więc zgodnie z Jego wolą, człowiek jednocześnie odkrywa w sobie „prawo grzechu” (Rz 7,23). Człowiek musi zrozumieć, że poznawszy Chrystusa może także w swojej wolności wystąpić przeciwko Niemu. Dlatego Paweł zachęca wiernych do walki z przeciwnikiem, to znaczy diabła, którym oddziela nas od Boga i wprowadza podziały między ludźmi,. Chrześcijan zatem powinien wystrzegać się wszystkiego, co jest może być przyczyną niezgody, napięć i podziałów. Jako konkretny przykład niebezpieczeństwa podziałów w pierwotnym chrześcijaństwie autorka omawia problem spożywania przez chrześcijan mięsa ofiarowanego idolom, co stanowiło realne zagrożenie jedności wspólnoty. 
W podsumowaniu tej części publikacji autorka wyraźne akcentuje, że podobnie jak w pierwszym wieku, tak i dzisiaj, nie wystarczy deklaracja wiary, ale przede wszystkim trzeba życie w zgodzie z wyznawanymi wartościami i prawdami. Wiara nie dotyczy tylko niektórych, pojedynczych aspektów ludzkiego życia, ale powinna wyrażać się w nowym stylu życia, w naszych wyborach rodzinnych, ekonomicznych i politycznych. To właśnie w życiu codziennym przychodzi królestwo Boże (s. 132).

W trzeciej części Reynier stawia pytanie o życie prawdziwie chrześcijańskie w społeczności, która jest ukierunkowana na przeżywanie przyjemności. Taki był niewątpliwie świat grecko-rzymski pierwszego wieku. Taki jest także współczesny świat. Najpierw Autorka omawia problematykę godności seksualności człowieka, jasno ukazując wręcz rewolucyjność chrześcijaństwa w stosunku do poglądów panujących w ówczesnym świecie. Nowa wiara, bazująca na nowej antropologii, akcentującej godność każdego człowieka, istotnie zmieniła podejście do praktyk prostytucji, pederastii rozumianej jako związki między dorosłymi mężczyznami a młodymi chłopcami, homoseksualizmu, wolności obyczajów, zwłaszcza związanych z życiem seksualnym. Chrześcijanin nie może praktykować żadnej z form nieczystości (zob. Ef 5,3), gdyż nie tylko uderzają one w godność człowieka, prowadzą do idolatrii i negacji innych, ale przede wszystkim absolutnie nie dają się pogodzić z nowym życiem w Chrystusie (zob. Ef 4,20-21).

Kolejny rozdział poświęcony został problematyce relacji małżeńskich oraz celibatu. Autorka rozpoczyna od przypomnienie, że w pierwszym wieku małżeństwo było postrzegane przede wszystkim jako konieczność społeczna, zwłaszcza w zakresie zapewnienia potomstwa. Paweł inaczej rozumie związek małżeński. Niewątpliwą nowością jest nauczanie apostoła, że mężczyzna w żaden sposób nie może dominować nad kobietą, zwłaszcza w sferze seksualnej. W tym kontekście autorka wyjaśnia także - niejednokrotnie kontestowane, zwłaszcza dzisiaj - nauczanie Pawła o tym, że kobieta ,została stworzona dla mężczyzny” (1 Kor $11,9)$ oraz nakaz, aby żony były poddane mężom (zob. Kol 3,18; Ef 5,22). W centrum Pawłowego myślenia o relacjach małżeńskich pozostaje miłość, która jest ponad wszystko. Małżeństwo nie jest tylko kontraktem prawnym, jak podkreślali to Rzymianie, ale tajemnicą, która odwzorowuje miłość Chrystusa do Kościoła. Stąd pozostaje ono nierozerwalne, a jedyny wyjątek stanowi tak zwany „przywilej Pawłowy” (zob. 1 Kor 7,13-15). Obok małżeństwa chrześcijaństwo promuje nową drogę życia, jaką jest celibat. Podsumowując tę część rozważań, autorka stwierdza, że instytucja małżeństwa w praktyce chrześcijańskiej bardzo szybko, niestety, zacznie być postrzegana z perspektywy prawnej, podobnie jak w prawie rzymskim, co spowoduje, że trudno będzie dostrzec w nim to, co jest specyficznie chrześcijańskie.

Ostatni rozdział trzeciej części został poświęcony wybranym zagadnieniom życia codziennego pierwszych chrześcijan. Reynier stara się pokazać, jak myśle- 
nie chrześcijańskie zmieniało świat i obyczaje tam, gdzie było obecne autentyczne świadectwo wyznawców Jezusa. Omawia kolejno kwestie: uroczyste formy świętowania, praca jako konieczność dla wszystkich, problem jedzenia, picia i postu oraz uroczystych uczt. W świecie hołdującym wszelkiego rodzaju przyjemnościom żyją także chrześcijanie, którzy czasami ulegają panującej modzie i obyczajom, i dlatego Paweł występuje zdecydowanie przeciwko wszelkim formom nadużyć prowadzących do odczłowieczenia i naruszenia godność ludzkiej. Apostoł przypomina uczniom Jezusa, że nic nie jest zabronione, ale wszystko winno być rozumiane i praktykowane w świetle Chrystusa, który uczynił człowieka wolnym. Właśnie ta wolność przynagla chrześcijan do tego, aby w różnych konkretnych sytuacjach życiowych objawiała się ich ludzka i chrześcijańska godność, a wtedy wiara, którą wyznają i praktykują, będzie kształtowała ich codzienność.

W ostatniej części publikacji autorka szuka odpowiedzi na pytanie, w jakim zakresie chrześcijanie, autentycznie praktykujący w codzienności swoją wiarę, stanowili wspólnotę oddzieloną od społeczeństwa, w którym żyli. To, co ich wyróżniało to niewątpliwie braterstwo, które było absolutną nowością w środowisku określanym jako społeczność asymetryczna, gdyż złożona z ludzi wolnych i niewolników, obywateli rzymskich i peregrinów (w prawie rzymskim termin ten stosowany był na określenie wolnych osób niebędących jednak obywatelami rzymskimi), mieszkańców miast i wsi, bogatych i biednych, cywilów i wojskowych. Każda z tych grup miała ściśle określone prawa i pozycję ekonomiczną, które je wyróżniały i stanowiły o ich określonej pozycji w ówczesnym społeczeństwie. Chrześcijaństwo i tutaj okazało się rewolucyjne, podkreślając jednoznacznie taką samą godność wszystkich bez wyjątku i głosząc przekonanie, że zwłaszcza niska pozycja społeczna nie może nikomu przeszkodzić w przylgnięciu do Jezusa (zob. 1 Kor 3,22-23). Paweł nie proponuje jakiś nowych struktur społecznych, ale zaprasza chrześcijan, aby wszędzie tam, gdzie żyją w wierności Jezusowi i praktykują pokój, przebaczenie i pojednanie, stawali się nowym zaczynem, który przemienia świat. W tym kontekście autorka przypomina także nauczanie Pawła odnoszące się do niewolników, które z jednej strony pozostaje wpisane $\mathrm{w}$ realia tamtego świata, z drugiej jednak jest oryginalne, gdyż mówi, że niewolników, którzy wyznają wiarę w Jezusa, mają łączyć braterskie więzy $\mathrm{z}$ ich panami.

Drugi rozdział czwartej części poświęcony został ukazaniu specyfiki wspólnoty chrześcijańskiej jako Kościoła, który jest zgromadzeniem ludzi w Bogu i Jezusie Chrystusie (zob. 1 Tes 1,1). Odnajdujemy tutaj syntetyczne omówienie wszystkich najważniejszych elementów składających się na eklezjologię Pawła: porównanie Kościoła do ciała Chrystusa, różnorodność i jedność wspólnoty, Eucharystia i Mistyczne Ciało Chrystusa, Kościół jako tajemnica, służba w proklamowaniu Dobrej Nowiny w świecie i dla świata, problemy pierwotnych wspól- 
not (jedność stołu podczas agap, troska o słabych, zwłaszcza wdowy i dzieci). Zdaniem Reynier największa, wprost rewolucyjna, nowość przyniesiona przez chrześcijaństwo to zjednoczenie w jednej wspólnocie żydów i pogan, którzy w ówczesnym społeczeństwie często pozostawali skonfliktowanych między sobą. Chcąc wyznawać Jezusa nie musieli rezygnować ze swoje kultury i języka. Autorka słusznie zauważa, że w świetle tekstów Nowego Testamentu, zwłaszcza Pawłowych, Kościół nie był wspólnotą idealną, ale pozwalał się kształtować przez słowo Boże, co jest zresztą konieczne dla Kościoła każdego czasu, aby pozostał rzeczywistym Kościołem Chrystusa.

W ostatnim rozdziale Reynier omawia kilka szczegółowych zagadnień: stosunek chrześcijan do przestrzegania zasad prawa i sprawiedliwości rzymskiej, odrzucenie wszelkich form pogoni za zaszczytami ziemskimi, stosunek do pieniędzy i bogactwa materialnego, płacenie podatków, stosunek do państwa i ideologii imperialnej, zabieganie o pokój Chrystusowy (inny jednak niż pax Augusta), ukazując specyfikę myślenia chrześcijańskiego w tych kwestiach. Autorka akcentuje, że wyrażone przez Pawła nauczanie chrześcijańskie zawsze postuluje, aby wyznawcy Jezusa, przeżywając i praktykując braterstwo, dyskretnie, ale konsekwentnie wpływali na kształt społeczności, w której żyją. Wierność Chrystusowi i Ewangelii w oczywisty sposób będzie czasami prowadzić do pewnych napięć, a nawet konfliktów z światem pogańskim, jednak chrześcijanie nie mogą przystosowywać się do świata, ale starać się go przemieniać. Zdaniem Reynier jest to prawdziwe wyzwanie rzucone każdej próbie wprowadzania uniwersalizmu za wszelką cenę i każdej władzy politycznej, zarówno w czasach Cesarstwa Rzymskiego, jak i współcześnie (s. 288).

Publikację zamyka konkluzja, przypisy do poszczególnych rozdziałów, bibliografia, indeks cytowanych autorów starożytnych i współczesnych oraz spis treści.

Recenzowana książka francuskiej biblistki to solidne i przekonywające studium o roli, a przede wszystkim niezwykłej sile i nowości Ewangelii. Wiernie i z przekonaniem wyznawana przez chrześcijan wiara powoli, ale bardzo konsekwentnie zmieniała świat, odkrywając prawdę o Bogu i człowieku oraz wnosząc zupełnie nowe wartości. Można powiedzieć, że w ten sposób uczniowie Jezusa, zafascynowani Jego osobą i dziełem, stali się światłością i solą ziemi, nadając nowy smak ówczesnemu światu. Reynier, wychodząc od myśli teologicznej apostoła Pawła, bardzo mocno podkreśla, że stało się to możliwe dzięki oryginalności Ewangelii, zwłaszcza w świecie pogańskim, ale także dzięki temu, że wyznawcy Chrystusa nie tylko przylgnęli do teoretycznych prawd w niej zawartych, ale związali swoje życie w Jezusem ukrzyżowanym i zmartwychwstałym. To dało im nadzwyczajną siłę, ale sprawiło również, że cierpliwie, nawet pośród przeciwności i prześladowań, starali się zmieniać świat, wierząc ostatecznie w ich zwycięstwo w Chrystusie zmartwychwstałym. Autorka kilkakrotnie, zresztą bardzo słusznie, przypomina niezwykłą wagę codziennego 
autentycznego świadectwa wiernych, wypływającego z wyznawanej wiary, ale przede wszystkim z przeżywanej relacji z Jezusem, która była i pozostaje fundamentalna, i jest konieczna, aby świeżość i nowość Ewangelii ciągle z tą samą mocą mogły kształtować współczesny świat, w którym żyją wyznawcy Jezusa. Można by powiedzieć, że lektura tej książki, będącej opracowaniem naukowym napisanym w sposób bardzo komunikatywny i angażujący czytelnika, staje się swoistego rodzaju „rachunkiem sumienia” zarówno dla wspólnoty, jak i dla pojedynczego chrześcijanina, pytaniem, na ile potrafimy dzisiaj dawać świadectwo naszej wiary, zdolne do „nawracania”, to znaczy proponujące inny sposób myślenia i życia współczesnemu człowiekowi i światu.

Na uznanie zasługuje także fakt, że publikacja jest kolejną udaną próbą przybliżenia czytelnikom niełatwej spuścizny teologicznej Pawła Apostoła. Autorka nie dzieli wypowiedzi apostoła na te o pewnym autorstwie (z listów protopawłowych) i te późniejsze (pochodzące z pism deuteropawłowych). Według Reynier cały dorobek literacki stanowi świadectwo tradycji Pawłowej, która bardzo jasno ukazuje główne punkty ciężkości nauczania Pawła z Tarsu, obejmujące nowe rozumieniem Boga, absolutne centralne miejsce Chrystusa ukrzyżowanego i zmartwychwstałego, dzieło Ducha Świętego, eklezjologię oraz nową antropologię z wszystkimi konsekwencje wynikającymi z niej dla życia człowieka w rozmaitych jego wymiarach duchowych i materialnych.

W zastosowanej metodologii Reynier jest bardzo konsekwentna. Aby ukazać oryginalność i nowość chrześcijańskiego przesłania, cytuje nie tylko teksty Pawłowe, ale konfrontuje je często z wypowiedziami autorów, zwłaszcza pogańskich, którzy także rozważali wiele kwestii szczegółowych, składających się na codzienność człowieka. $Z$ jednej strony pozwala to czytelnikowi zrozumieć, że Paweł podejmował w swoich listach najważniejsze kwestie egzystencjalne, z którymi stykali się chrześcijanie pierwszego wieku i niejednokrotnie borykali się z nimi, z drugiej zaś - umożliwia lepsze zrozumienie nowości chrześcijańskiego przesłania oraz jednoznacznie ukazuje, że wiara chrześcijańska nie pozostawała teoretyczną refleksją o Bogu, człowieku i świecie, ale miała wymiar na wskroś egzystencjalny, kształtując codzienne wybory chrześcijan. To przesłanie wydaje się bardzo aktualne w dzisiejszym czasie. W tym właśnie kontekście autorka w wielu miejscach zaznacza, że bardzo konkretne i jednocześnie koherentne do wyznawanej wiary postawy uczniów Jezusa są pożądane i oczekiwane także dzisiaj. W tym znaczeniu publikacja pozwala czytelnikowi odkryć także, jak nauczanie Pawła Apostoła, mimo że spisane w zupełnie innym kontekście historycznym, społecznym i kulturowym, pozostaje nośne i aktualne dla współczesnego chrześcijaństwa.

Na koniec chciałbym zwrócić uwagę na jeszcze jeden bardzo ważny i aktualny aspekt recenzowanej publikacji. Dzisiaj często w różnego rodzaju dyskusjach, także w kręgach chrześcijańskich, przypomina się Kościołowi i wyznawcom 
Jezusa tak zwane ciemne karty historii i próbuje się przedstawiać chrześcijan, zwłaszcza katolików, jako fanatyków i zwolenników zacofanych koncepcji, przypisywać im odpowiedzialność niemal za każde zło, które się działo i dzieje w świecie. Często zapomina się albo świadomie przemilcza dobrodziejstwa, które światu przyniosła Ewangelia, mająca swój istotny udział w kreowaniu nowego człowieka i społeczeństwa. Taki sposób myślenie niejednokrotnie nie jest obcy także ludziom, którzy uznają się za wierzących, a przynajmniej praktykujących chrześcijan. Książka Reynier wydobywa i przekonywająco ukazuje ową oryginalność wiary chrześcijańskiej, która odcisnęła niezatarte ślady w świecie pierwszego wieku, znamiona które obecne przez setki lat, odnajdujemy także dzisiaj. W książce autorka podejmuje tematy dotyczące także współczesnej kultury, często powracające $\mathrm{w}$ debacie publicznej: sprawiedliwość społeczna, seksualność człowieka, prawa ludzkie, status kobiety oraz powszechne braterstwo wszystkich ludzi. Czytając recenzowane studium, uświadamiamy sobie najpierw, że nie są to tylko tematy współczesnych czasów, ale interesowały one także pierwszych wyznawców Jezusa. Wobec różnego rodzaju pytań znajdowali przekonywające ich odpowiedzi w wierze, którą wyznawali, i proponowali je ówczesnemu światu. W ten sposób Ewangelia stała się źródłem inspiracji i przemiany świata. A skoro prawdy te wypływają z Ewangelii, to znaczy od Chrystusa zmartwychwstałego, to nie tracą nic ze swej aktualności i mocy, a dla chrześcijan pozostają cennymi wartościami, które nie tylko trzeba przypominać, ale przede wszystkim kierować się nimi w życiu i w ten sposób pozwalać im nadal kształtować świat, w którym uczniowie Jezusa wyznają swoją wiarę. Książka Reynier jest zatem kolejną zachęta, aby dzięki wiernemu świadectwu chrześcijańskiej wiary, Ewangelia pozostała nadal „wielkim kodem kulturowym” także współczesnego świata. 